\title{
AESTHETICS OF UNSPOKEN : ARCHITECTURAL FORM AND VISIBLE BOUNDARY OF LANGUAGE
}

\section{A B S T R A C T}

Stonborough House is a house in the heart of the city of Vienna that was, apart from architect Paul Engelmann - a disciple of Adolf Loos, designed and constructed by philosopher Ludwig Wittgenstein, at the suggestion of his sister Margaret Stonborough-Wittgenstein. In an attempt to connect Wittgenstein's philosophy with his work as an architect, the Stonborough House has often been named 'a visible form of his teaching'. Therefore, this paper intends to point out that translation into a substitute language of architecture became a meaningful way of addressing philosophical issues, and that the credo of Wittgenstein's philosophical ethics, which was restraint from the redundant, found articulation of its aesthetic value through architectural rhetoric.

Vladimir Stevanović

Singidunum University of Belgrade - Faculty of Media and Communications

KEY WORDS

Andrea Raičević 
INTRODUCTION

Your whole body, from wingtip to wingtip ... is nothing more than your thought itself, in a form you can see.

Ričard Bah, Galeb Džonatan Livingston (Beograd: Mono \& Mañan, 2005), p. 55

Stonborough House ${ }^{1}$ is a house in the heart of the city of Vienna that was, apart from architect Paul Engelmann - a disciple of Adolf Loos, designed and constructed by philosopher Ludwig Wittgenstein, at the suggestion of his sister Margaret Stonborough-Wittgenstein. In an attempt to connect Wittgenstein's philosophy with his work as an architect, the Stonborough House has often been named 'a visible form of his teaching'. ${ }^{2}$ The Stonborough House was constructed in the period 1926-28, at the time of Wittgenstein's 'philosophical silence' (1919-28), as referred to by Gajo Petrović in the postface of Tractatus ${ }^{3}$ - and can be seen as a way for Wittgenstein's 'insistence on a certain philosophical position'4 to remain silent, i.e. a way to prove that a philosophy that cannot be communicated sensibly does not confirm its redundancy by repetition and search for its articulation in speech.

In general, Wittgenstein followed the idea of reducing philosophy to the issue of language - so it is not that hard to believe that he also tried (at visible places; in the material) $)^{5}$ to present philosophical issues through their linguistic and logical nature. Jelena Berberović wonders whether this reduction can go without consequences, and whether philosophical issues can really 'vanish' by solving linguistic confusions and imprecisions. ${ }^{6}$ In a BBC documentary called Sea of Faith, philosopher Don Cupitt describes Stonborough House emphasising the importance of reduction as the omitted - the unspoken: "And as with his philosophy what's left out is even more important than what is left in."

This paper intends to point out that translation into a substitute language of architecture became a meaningful way of addressing philosophical issues. Silence gained tangible value in architecture. Having chosen the language of architecture as a type of abstraction and simplified translation of the natural language, Wittgenstein could create a ground for testing the boundaries of language by restricting the linguistic domain. It is our opinion that the language of architecture indirectly proved to be the way to remain silent on what cannot be spoken: ${ }^{8}$ in an attempt to supress and deafen the inarticulable, but also to present, understand and interpret it through architecture that is in itself defined by a gap or an abyss between the visible and the articulable, between the unverbal and verbalisation; and that the credo of Wittgenstein's philosophical ethics, whose motto was 'restraint from the redundant', found articulation of its aesthetic value through architectural rhetoric. 
At the end of the nineteenth and the beginning of the twentieth century, Europe was balancing between historicistic tendencies - academism and eclecticism, and their opposing reactionistic general tendencies for finding and establishing the new, reformist and complete style of Art Nouveau that aims at liberalising art. ${ }^{10}$ In the light of the age of industrialisation that brought accelerated technological progress and change of the pace of life, Klaus-Jürgen Sembach sees Art Nouveau as a style "striving to bring about a reconciliation between traditional expectations in art and the modern face of technology", unlike historicism which was in the least indifferent to any form of dialogue. ${ }^{11}$ The Austrian version of Art Nouveau - Secession, was the main subject of criticism that Adolf Loos, a follower himself in the beginning but also its stern critic after having lived in America ${ }^{12}$, expresses in his essay Ornament and Crime. ${ }^{13}$

The Vienna of Wittgenstein's time was characterised by the clash between the aesthetic and the ethic aspect of artistic expression, reflected in reviewing the justification for every form of creation. Hyper-productivity of industrial production and technological progress that threatened to dehumanise creation and lose the aura of an artistic object was equalled to the debauchery attributed to superfluity, directness and excessiveness. Redemption for unjustifiable, disinterested and deaestheticised creation for the sake of creation was sought in restraint, criticism and review. ${ }^{14}$ Wittgenstein directed this restraint towards searching for an external determinator of cognition - rules and instructions that would subject language, and thus also its living form, to a logical system, trying to attain accuracy through liberation from excess. Wittgenstein's philosophy is characterised by faith in the interconditionality of things where the instruction for the said liberation lies: In a simultaneous and multi-isomorphic operation ${ }^{15}$ (with a finite number of variables), Wittgenstein determines conditions under which something is possible, but also, at the same time, determines what is possible under the given conditions. ${ }^{16}$

Written accounts of architect Paul Engelmann who found himself in the role of a mediator, an interpreter and a chronicler at the crossroads between architecture, philosophy and critical thinking, leading a "life in the shadows of his three mentors"17, are important for us as attestations of social and cultural aims of Vienna and indicators of the roots of Wittgenstein's interest in architecture characterised by restraint from polysemy. ${ }^{18}$

Engelmann acquired comprehensive and thorough understanding of numerous spheres of public life of the Vienna of the time and gave an aphoristic, critical review of the experience of working with his mentors: He "learned something from them: From Kraus not to write, from Wittgenstein not to speak, from Loos not to build". ${ }^{19}$ 
"Not to" can be seen as active restraint from discursive and targeted action. Through the theoretical practice of architect Adolf Loos, we will analyse the characteristics of this passive activism in order to view Wittgenstein's architectural decisions as mediated.

At the dawn of the establishment of new modernism, in his critical review of tradition, Loos turned towards reconsideration of fundamental bases of architecture. Loos' contradiction to decoration does not intend to abolish or forbid the style, but it calls for the redefinition of the term, embodying a thought that to be modern is to live according to the zeitgeist.

Every period had its style: why was it that our period was the only one to be denied a style? By "style" was meant ornament. I said: Weep not! See, what makes our period so important is that it is incapable of producing new ornament. We have out-grown ornament, we have struggled through to a state without ornament. ${ }^{20}$

Linking the level of development of the civilisation and the character of its artistic expression, its clarity and directness, Loos sees early forms of artistic expression as primitive responses to instinct, and ornament as their indicator. He considers their sublimation as civilisational heritage in which complete purification and the absence of the need for expression in a form is seen as the end goal. "I have made the following observation and have announced it to the world: The evolution of culture is synonymous with the removal of ornament from objects of daily use." 21 Therefore, he showed that ornament is the architectural form of (un)related rudimentary references to the past and symbolism that is unjustified in the zeitgeist. ${ }^{22}$ Loos strived to rid the form of decoration. For Loos, architecture is not art. ${ }^{23}$ Aesthetic value of architecture is placed outside of direct observation: it transforms towards the notion of perfect, true, complete, sufficient, and practical. ${ }^{24}$

We see Loos as the founder and translator of the fundamental (linguistic) instances of architectural expression important for the formation of (future) modernistic foundations of architecture and international style in their dialectic relation with time. Elementary and refined vocabulary and syntax of architectural expression that Loos introduced replaced and purified the architectural thought, modelling it according to the principles of a function that Loos translated as the use value.

We emphasise the parallel with Wittgenstein: "The meaning of a word is its use." ${ }^{25}$ In the act of translation, Wittgenstein is not interested in the change of meaning but in the constant in the relation. The use of the language of architecture 
as means of translation can be interpreted as a use where the understanding of the targets of that use is found in the meaning. Wittgenstein believes that reasoning is what forms the world into a structure: internal structure establishes the secular, therefore, language as a medium of expression is arbitrary, and the expressed is always the image of such structure.$^{26}$ However, the form of such structure is visible depending on its medium.

For Wittgenstein, even the very use of a language is a part of an activity or a form of life. ${ }^{27}$ Its use (or its (im)possibility) is a rule in itself. The use of the language of architecture, in which an intrinsic intention of one language is expressed by means of another ${ }^{28}$, is its formalisation, while architectural reality is its result. Wittgenstein says: "To imagine a language means to imagine a form of life". ${ }^{29}$ If architecture is a formal language, then its form of life is also an artificial form.

By religious dedication to detail and profiling from general to individual, everything in the Stonborough House was brought to maximum usability in such a way that the form itself becomes the instruction manual. ${ }^{30}$ Wittgenstein ensures maximum surrender of an object to its given role. The superposition of adopted characteristics of space guarantees that surrender. The architectural element - the word - has nowhere to go. ${ }^{31}$ It is provided with grammatical, syntactical, and therefore applicable - practical unambiguity; it is polished to muteness, ${ }^{32}$ to the limits of communication. It is stripped of everything that does not define it in function. As such, it is left at edge of the will to fulfil its syntactic function, at the verge of sentence resistance.

By ruthless (anti)stylisation, the individual has taken primacy over the whole: An object freed from excesses reaches completeness ${ }^{33}$ on its way to the boundaries of language, as well as its maximum articulation that ensures its exactness, unambiguity and self-sufficiency.

Architecture is a means to express something else, the process of its creation is a mediator function in denoting one notion with another, and mastering its technique does not mean mastering communication by architecture, but merely communication using the language of architecture; not even 'in' architecture. ${ }^{34}$ Architectural presentation is the instrumentalisation of the natural language, a communication model used for discursive communication within it. ${ }^{35}$ This is a kind of a transformation of what was meant to be said into its presentation in speech, into the result itself - communication through the equalisation of the two. For Wittgenstein, construction becomes: thinking by the use itself: (...) "thinking in some form or other a different sentence from the one you utter?"36 
To build architecture is to handle, use and contemplate its materiality, to enter into the linguistic field of its final formal expression. To build would mean to think through architecture. ${ }^{37}$ For Wittgenstein, to build could mean to still be able to stay silent while, at the same time, verbalising something in a form.

\section{I}

Wittgenstein allegedly said: "I am not interested in erecting a building, but in $[\ldots]$ presenting to myself the foundations of all possible buildings" ${ }^{38}$ The foundation of all possible buildings is their lowest common multiple. In this case, optimisation is brought to idealisation. Searching for the foundation of all possible buildings, Wittgenstein is searching for a way to express everything that has to be said through the lowest number of relations among words. It can be interpreted that the meaning, like the name assigned to a thing, is arbitrary. Hierarchical relation is more important than the meaning. In the scope of what will become the framework of his Philosophical Investigations, ${ }^{39}$ words become the endpoints of the space 'in between' that is actually a defining space of what can be articulated with them. In his Investigations words become chess pieces, tools on whose behalf their use speaks and stands. They become its justification.

Judging by Wittgenstein's affinity for searching for an ideal form (of language) (0 $^{40}$ in which everything is defined with precision (beyond its own boundaries), with a view to eliminating the possibility of a mistake (exclusively due to linguistic reasons ${ }^{41}$ ), we can say that the foundation of all possible buildings could be the boundary of language in a visible form. Its visible form translated into meaning represents a kind of the maximum of the minimum - the maximum of exactness and perfection ${ }^{42}$ expressed by the minimum of necessary language tools, and the minimum of the state of affairs prejudiced in things..$^{43}$ Wittgenstein's foundation contains instructions for all other possibilities of the state of affairs and does not allow for anything that could be redundant or unestablishable as a relation.

The foundation of all possible buildings is a starting point from which every (linguistic) possibility of architecture can be created, in which every possibility is stated and said, it is a rule, a source, it is an origin. Here we are following

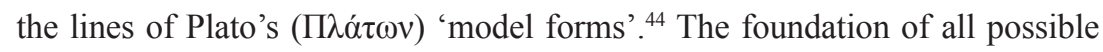
buildings may be an experimental presentation (trial) of the place of the khôra $(\chi \omega ́ \rho \alpha)^{45}$, but certainly devoid of its defining immateriality (void of all forms), unframability (externality) and disparity (dissimilarity with what is being founded). ${ }^{46}$ This devoidness is the product of the language medium and its presenting function that gives a single meaning to the mythos in the logos, and to the intelligible in the sensible, thus leaving a gap or an abyss - the unarticulated, while, in the positive of this void, it leaves deficiency and incompleteness. From 
the aspect of architecture as presentation, this incompleteness is registered and accepted as part of the objective formal expression, and is considered a key condition for establishing architectural otherness by completion that in its temporal and formal duration is achieved as promised in the 'yet to be'. ${ }^{47}$ Silence and refraining from excess in speech that are the weapon of intention, become the condition of self-expression of architecture.

\section{I I}

If there are lessons Wittgenstein learns from practicing architecture, they can be described through his search for an ideal object. An ideal object is not a form of results, it is a form of possibilities, an affirmative answer to the question of its own potential existence. This object would be, in the full abstraction of language, nothing else but - a relation. For Wittgenstein, an object is ideal if it is a complete and unambiguous product of the system that formed it. By going beyond, or by entering into the extralinguistic level of that system, it loses its meaning. If we have understood it, we have surpassed it, and climbed the ladder above it. In the Stonborough House, we are always on the ladder ${ }^{48}$ : we see it, but the metaliguistic structure of the language which is the language of its use is such that the system in which the house was built surpasses it, because the house itself is not included in the system, and to it, the system may seem meaningless.

Wittgenstein's interest in a house ends before the idea of a house as a place to live in. He reckons that such epilogue is consequently included in every construction that followed the guidelines and limitations of its own medium of expression.

A system within which and for which something is created is a system in which that something (and the system itself) is meaningful and subject to use. For Wittgenstein's house, its use is a metalinguistic penetration into its linguistic structure. ${ }^{49}$ However, an attempt to explain this house by its use is futile because its structure was not intended to be used for a founding and programming purpose, therefore, such unverbal leaking of what was hidden from intention (of what was to be imposed to construction, of how architecture was to be used for personal benefit and issues) remained marked in the structure, but it has become unintelligible in the use for which it is not intended.

However the purpose of architecture does not have to be exclusively architectural, meaning that (for example) so called spiritual being ${ }^{50}$ that can be discovered in its language is not a being which carries the need to fulfil its purpose only and exclusively through use, though it never cancels it. This conclusion can 
be drawn from the statements on the Stonborough House deeming it unfit for living $^{51}$, and those statements are based on the expectations of architecture: understanding the function itself as a possibility of use. Since this possibility is not removed, we can conclude that this result is only an experiential deviation related to the experience of space through association with the already familiar and the impossibility of a dialogue with the unspoken.

Also known as the Wittgenstein House.

Don Cupitt, "The New World” ep. 6, in Sea of Faith (London: British Broadcasting Corporation - BBC, 1984), 33:20.

Tractatus Logico-Philosophicus was published in 1922.

Gajo Petrović, "Logički atomizam i filozofija neizrecivog u Tractatusu Ludwiga Wittgensteina," in Ludvig Vitgenštajn, Tractatuslogico-philosophicus (Sarajevo: IP "Veselin Masleša", 1987), p. 196.

The reduction was applied in the interior design and the design of the object in use: paving, radiator, window and door handles, which brought these elements to the utmost simplicity and utter functionality. Cupitt, "The New," 33:32. The decision that all door and window frames, as well as fittings, should be metal was made because only metal is a material that can ensure satisfying precision. See John Hyman, "The urn and the chamber pot," in Wittgenstein, Theory and the Arts, eds. Richard Allen and Malcolm Turvey (London - New York: Routledge, 2001), p. 145. 
Cupitt, "The New," 34:00.

Ludvig Vitgenštajn, Tractatuslogico-philosophicus (Sarajevo: IP "Veselin Masleša", 1987), T7: "Whereof one cannot speak, thereof one must be silent" (Letter T followed by the number of statement, instead of the number of the page where the quoted text is located, shall directly refer to the herein referred bibliographic unit)

Kata Marinović Cvijin, “Unesco - Jugendstil, Art Nouveau/Darmstadt - Heiligkreuytal.”, Rukoveti - časopis za književnost, umetnost $i$ društvena pitanja, no.5 (1986): p. 464-473.

The phrase "To every age its art. To every art its freedom." stands at the entrance into the Secession building in Vienna, constructed by architect Joseph Maria Olbrich in 1887, and is considered the manifest of the movement. Paradoxically, by introducing art into the most intimate areas of life, under the maxim of freedom, such direct way of commitment to detail caused a complete subordination of the life of art, and lifestyle, so much that some artists stopped creating. ibid.

Klaus-Jürgen Sembach, "Art Nouveau: The Modern Style's First Steps,“ in Istorija moderne arhitekure - knjiga 1. Koreni modernizma, ed. Miloš R. Perović (Beograd: IDEA: Arhitektonski fakultet univerziteta u Beogradu, 1997 [1991]), p. 393, 397.

Sembach concludes that the responses of historicism and Art Nouveau to technological progress are in fact various strategies of rebellion against the growing autonomy of technology and its penetration into the areas that once belonged to art only: "While historicism was trying to defend its territories from the inconceivable phenomenon of technology by evoking the past, Art Nouveau was risking artistic intrusion into the enemy zone to reclaim the lost territories."

Living and working in America in the period 1983-1986, when the Chicago School of architecture was thriving, was crucial for Loos' decision to distance himself from the influence of the doctrine promoted in Vienna by Otto Wagner. Panayotis Tournikiotis, "Adolf Los: tekstovi projekti zgrade," in Istorija moderne arhitekure - knjiga 1. Koreni modernizma, ed. Miloš R. Perović (Beograd: IDEA: Arhitektonski fakultet univerziteta u Beogradu, 1997 [1994]), p. 550-551.

Adolf Los, Ornament i zločin (Zagreb: Mladost, 1952)

About this read in Allan Janik, Stephen Toulmin, Wittgenstein's Vienna (New York: A Touchstone Book, 1973), p. 33-66.

As it is stated in the Janik, Wittgenstein's, p. 185: "Two things, accordingly, are essential to Wittgenstein's model theory of language: a correspondence theory of truth, and the assumption that there exists a sufficient "isomorphism" (Verbindung) between language and reality to permit and validate - all our descriptive use of language." In this respect Wittgenstein's house can be seen as a way of comparison of a model of thoughts and reasoning with the state of affairs in reality: "in order to tell whether a model is true or false, we must compare it with reality." (Vitgenštajn, Tractatus, T 2.223)

This is a closed system that one can leave by climbing beyond its boundaries (Wittgenstein's ladders - see Vitgenštajn, Tractatus, T6.54). He provides the image of reality by listing all possible propositions corresponding to the conditions of the state of affairs and all possible relations these conditions are subject to. Through confrontation and application of all rules, only that what is possible is achieved. Rules make a rule. If the world can be described as finality, finality can be described as a set of rules, and this set of rules can be defined within a rule that encompasses them all.

His mentors were: Loos, Wittgenstein and Kraus. See Anne-Louise Sommer, "Modern architecture: a proces of radical rethinking," in Architecture, Language, Critique: Around Paul Engelmann, eds. Judith Bakacsy, A. V. Munch and Anne-LouiseSommer (Amsterdam - Atlanta GA: Forschungsinstitut Brenner-Archiv, 2000), p.17.

Liberation from excesses is the Loosian imperative, but it has different motivation for Wittgenstein. Wittgenstein is not afraid of polysemy and mistakes made due to incomprehensive definitions, while Loos speaks into the void (in conection with the famous Loos'essay Spoken into the void), into a meaningless space; for Wittgenstein, excess is undesirable, while for Loos it is redundant, for Wittgenstein excess is a threat, for Loos - a bluff. 
Sommer, "Modern," p. 16.

Los, Ornament, 9.

ibid. p. 8 .

ibid. p. 13.

"Everything serving a purpose must be excluded from the reign of art" See Los, Ornament, p. 24.

According to Alberti in Los, Ornament, p. 29. "An object that is so perfect that one can neither add to it nor take away from it without harming it, is beautiful."

According to Ludvig Vitgenštajn, Filosofska istraživanja (Beograd: Nolit, 1969), §60 and $§ 61$ (Symbol $\S$ followed by the number of the paragraph, instead of the number of the page where the quoted text is located, shall directly refer to the herein referred bibliographic unit)

In conclusion after reading Vitgenštajn, Tractatus: When the (philosophical) truth about the world is conditionally known or given in itself, it represents a system that is entirely self-referential and self-defining. Regardless of what the truth is, it is conditioned by itself in a way that it defines itself, therefore, it is futile to talk about such truth as of possibly different.

Vitgenštajn, Filosofska, §23.

ibid. $\S 334$

ibid. $\S 19$

See Loos' text The Master Saddler. Adolf Los, "Sedlar," in Izabrani eseji, eds. Ljiljana Blagojević and Dejan Vlaškalić (Beograd: Grupa Lavirint, 2000 [1910]).

See Janik, Wittgenstein's, p. 185. "The logical structure of language makes it possible for us to ascertain a priori that certain configurations of objects are, or are not, "possible." (...) Given all the possible "truth values" for the symbols a proposition contains, it can be determined which of these are truth possibilities, given the sense of the proposition - that is, what relation it asserts or denies to hold between the symbols." To give those "truth values" in this case is to try to establish all possible propositions of a logical space in a real space in a way that the whole space is already given and dependent of propositions in the same time as it conditions them: "It determines a certain configuration of objects by asserting or denying a logical connection between symbols; and by assigning all possible truth values to these symbols, the conditions under which the proposition can be true or false are established." (Janik, Wittgenstein's, p. 185.)

“Silence tells no lies; silence doesn't deceive." Cupitt, "The New," 35:22.

See note 24 .

Benjamin, Eseji, p. 31. (...) "All language communicates itself."

Berberović, "Problemi jezika,” p. 31. (...) "language (is) an instrument of communication, ... to master it means to master a technique that helps us communicate with other people and influence them."

Vitgenštajn, Filosofska, § 19

Even Heidegger who considered that "Language is the house of Being" (as cited in Miloš Šumonja, "Vitgenštajn i Hajdeger: jezik kao univerzalni medijum i neiskazivost semantike", Theoria 3 (2012): 55: p. 124.) emphasised the essence of building as thinking. Martin Heidegger, "Građenje, stanovanje, mišljenje," in Teorija arhitekture i urbanizma, eds. Petar Bojanić and Vladan Đokić (Beograd : Arhitektonski fakultet, 2009 [1967]), p. 115-124.

The statement can be found Richard Sennett, The Craftsman, (New Haven, Connecticut: Yale University Press, 2008), p. 254.

Ludvig Vitgenštajn, Filosofska istraživanja (Beograd: Nolit, 1969)

Berberović, "Problemi jezika,” p. 23-25.

ibid. p. 31 . 
ibid.

According to Vitgenštajn, Tractatus, T 2.012

Walter Benjamin, Eseji (Beograd: Nolit, 1974), p. 21.

If every system of knowledge is based on the language of 'model copies', we may conclude: the logic of one world is the logic of a reasoning whose meaning is embodied in the logic itself and is incomprehensible and inapplicable outside that world. According to Endrju Bendžamin, Filozofija arhitekture (Beograd: Clio, 2011), p. 21.

See ibid. p. 23.

ibid. p. 24. Non-architectural and immaterial is manifested through the interaction of space and time according to the principle of the 'yet to be' concept introduced by Andrew Benjamin (ibid. p. 13), through which the manifestation of architecture in its essence of the linguistic formal expression delves into the field of (its) otherness.

Vitgenštajn, Tractatus, T6.54 "My propositions serve as elucidations in the following way: anyone who understands me eventually recognizes them as nonsensical, when he has used them - as steps - to climb up beyond them. (He must, so to speak, throw away the ladder after he has climbed up it.)"

In the introduction of Tractatus logico-philosophicus Bertrand Russel provides his interpretation and states: (...) "every language has (...) a structure concerning which in the language, nothing can be said, but that there may be another language dealing with the structure of the first language, and having itself a new structure, and that to this hierarchy of languages there may be no limit." (Bertnard Russel, "Uvod" in Vitgenštajn, Tractatus, p. 19) Or as Wittgenstein himself claims: "No proposition can say anything about itself, because the propositional sign cannot be contained in itself" (T 3.332), or in mathematical terms: "A function cannot be its own argument..." (T 3.333).

Walter Benjamin clearly sees this problem of understanding the language of things whose spiritual being is impossible to relate to its associated linguistic being in the need to denominate (and further, through that need, in the need to speak, write down, read etc.) See Benjamin, Eseji, p. 32: "It should not be accepted that we know of no languages other than that of man, for this is untrue. We only know of no naming language other than that of man."

Wittgenstein's sister, Hermine, wrote: "Even though I admired the house very much, I always knew that I neither wanted to, nor could, live in it myself. It seemed indeed to be much more a dwelling for the gods than for a small mortal like me." See Nana Last, Wittgenstein's House: Language, Space, \& Architecture (New York: Fordham University press, 2008), p. 82. 
Benjamin, Walter. Eseji. Beograd: Nolit, 1974.

Berberović, Jelena. "Problemi jezika u filozofiji Ludwiga Wittgensteina" In Vitgenštajn, Ludvig. Filosofska istraživanja. 9-34.Beograd: Nolit, 1969.

Cupitt, Don. "The New World” (episode 6), Sea of Faith. produced by P. Armstrong. (1984; London: British Broadcasting Corporation - BBC. 12. November 2013.) https://www.youtube. com $/$ watch? $=$ CsD50TdmZEs (ac. 20.8.2017.)

Hajdeger, Martin. "Građenje, stanovanje, mišljenje” In Teorija arhitekture i urbanizma, edited by P. Bojanić, and V. Đokić, 115-124. Beograd : Arhitektonski fakultet, 2009 [1967].

Hyman, John. "The urn and the chamber pot" In Wittgenstein, Theory and the Arts, edited by R. Allen and M. Turvey, 137-153. London - New York: Routledge, 2001.

Janik, Allan. Toulmin, Stephen. Wittgenstein’s Vienna. New York: A Touchstone Book, 1973.

Last, Nana. Wittgenstein's House: Language, Space, \& Architecture. New York: Fordham University Press, 2008.

Los, Adolf. Ornament i zločin. Zagreb: Mladost, 1952.

Los, Adolf. "Sedlar" in Izabrani eseji, edited by Lj. Blagojević and D. Vlaškalić. Beograd: Grupa Lavirint, 2000 [1910].

Marinović Cvijin, Kata. "Unesco - Jugendstil, Art Nouveau/Darmstadt - Heiligkreuytal”, Rukoveti - časopis za književnost, umetnost $i$ društvena pitanja, no.5 (1986): 464-473.

Petrović, Gajo. "Logički atomizam i filozofija neizrecivog u Tractatusu Ludwiga Wittgensteina" In Vitgenštajn, Ludvig. Tractatuslogico-philosophicus. 191-236. Sarajevo: IP "Veselin Masleša", 1987.

Russell, Bertrand. "Uvod” In Vitgenštajn, Ludvig. Tractatuslogico-philosophicus. 5-19. Sarajevo: IP "Veselin Masleša”, 1987 [1922].

Sommer, Anne-Louise. "Modern architecture: a proces of radical rethinking” In Bakacsy, Judith. Munch, A. V. and Sommer, Anne-Louise. Architecture, Language, Critique: Around Paul Engelmann. 16-24. Amsterdam - Atlanta GA: Forschungsinstitut Brenner-Archiv, 2000.

Sembach, Klaus-Jürgen. "Art Nouveau: The Modern Style's First Steps" In Istorija moderne arhitekure - knjiga 1. Koreni modernizma, edited by M. Perović R, 393-399. Beograd: IDEA: Arhitektonski fakultet univerziteta u Beogradu, 1997 [1991].

Sennett, Richard. The Craftsman. New Haven, Connecticut: Yale University Press, 2008.

Šumonja, Miloš. "Vitgenštajn i Hajdeger: jezik kao univerzalni medijum i neiskazivost semantike", Theoria 3 (2012): 55: 113-137.

Tournikiotis, Panayotis. “Adolf Los: tekstovi projekti zgrade” In Istorija moderne arhitekure knjiga 1. Koreni modernizma, edited by M. Perović R, 550-573. Beograd: IDEA: Arhitektonski fakultet univerziteta u Beogradu, 1997 [1994].

Vitgenštajn, Ludvig. Tractatuslogico-philosophicus. Sarajevo: IP "Veselin Masleša”, 1987.

Vitgenštajn, Ludvig. Filosofska istraživanja. Beograd: Nolit, 1969. 


\section{OSNOVNA PITANJA I ZNAKOVI - ESTETIKA ARHITEKTURE Miško Šuvaković}

U ovom radu autor postavlja osnovna pitanja o estetici arhitekture. Arhitektura, kao strateški dispozitiv zgrade/građevine, i urbanizam, kao strateški dispozitiv grada, transformišu prostorno (geografsko) i vremensko (istorijsko) stanje u dispozitiv oblika života, čime se razvijamo kao pojedinci i zajednice ljudi u našim pojavnim oblicima prostora i vremena u određenom trenutku. Zato je neophodna politizacija građevine - arhitektonska i umetnička - arhitektonske prakse. To znači pokazati gde se organizacija životnog prostora suprotstavlja organizaciji načina života pojedinca i zajednice. Politika arhitekture je antropologizovana, a to znači da arhitekte/gradski planeri rade tako da arhitekturu orjentišu prema objektu ili odnosu objekata koji utiču na ljudski život svojim svakodnevnim fleksibilnim i složenim intimnim, privatnim i javnim izgledom.

KLJUČNE REČI: ARHITEKTURA, ESTETIKA ARHITEKTURE, DISPOZITIV, NAČINI ŽIVOTA, PRAKSA

\section{ESTETIKA I SHVATANJE MOBILNE REALNOSTI: ARHITEKTONSKA PERSPEKTIVA \\ Vladimir Mako}

U ovom radu se raspravlja o mogućnosti da ideja mobilne realnosti iz teoretske perspektive nekoliko značajnih filozofa sa početka dvadesetog veka I savremenih arhitektonskih ideja budu komplementarne po dinamičkim karakteristikama estetske percepcije I iskustva. Ova, na prvi pogled čudna izjava, mogla bi se opravdati relativnom sličnošću filozofskih I arhitektonskih ideja početkom dvadesetog I dvadeset prvog veka, izloženih kroz njihove osnovne karakteristike. U stvari, dinamički estetski doživljaji su osnovne vrednosti avangardnog razumevanja arhitektonskog I urbanog dizajna, a ideja mobilne realnosti je jedna od njihovih osnovnih ideja. Ove ideje bi se mogle primeniti u različitim pristupima dizajna I dinamičkih estetskih doživljaja u savremenoj arhitekturi.

KLJUČNE REČI: ARHITEKTURA, MOBILNA REALNOST, ESTETIKA, PERCEPCIJA

\section{ESTETIKA PREĆUTANOG: \\ ARHITEKTONSKA FORMA I VIDLJIVA GRANICA JEZIKA \\ Vladimir Stevanović, Andrea Raičević}

Stonborough House je kuća u gradskom tkivu Beča na čijem je dizajnu i realizaciji austrijski filozof Ludvig Vitgenštajn učestvovao zajedno sa arhitektom Polom Engelmanom učenikom Adolfa Losa, na predlog svoje sestre Margaret Stonbro-Vitgenštajn. U pokušaju da se Vitgenštajnova filozofija dovede u vezu sa njegovim radom kao arhitekte, kuća Stonborough često je imenovana 'vidljivom formom njegovih učenja'. Ovaj rad ima za cilj da pokaže da je prevođenje na zamenski jezik arhitekture dobilo smisao kroz bavljenje filozofskim pitanjima i da je kredo Vitgenštajnove filozofske etike - uzdržavanje od izlišnog, pronašao artikulaciju svoje estetske vrednosti posredstvom arhitektonske retorike. 